\title{
MITOTIC INDEX AND CELL PROLIFERATION KINETICS AS ADDITIONAL VARIABLES FOR ASSESSMENT OF GENOTOXIC EFFECT OF THE HERBICIDE MODOWN
}

\author{
K. ŠIVIKOVÁ, J. DIANOVSKÝ \\ Department of Veterinary Genetics, University of Veterinary Medicine, \\ Košice, Slovak Republic \\ Received September 2, 1999 \\ Accepted February 10, 2000
}

Abstract

Šiviková K., J. Dianovský: Mitotic Index and Cell Proliferation Kinetics as Additional Variables for Assessment of Genotoxic Effect of The Herbicide Modown. Acta Vet. Brno 2000, 69: 45-50.

The in vitro effect of the herbicide Modown (with active component bifenox) was tested for the ability to influence cell proliferation of PHA-stimulated bovine peripheral lymphocytes. Mitotic (MI) and proliferation (PI) indices were determined as an alternative for the screening of the cytostatic activity. The herbicide Modown exerted a clear effect on the inhibition of MI and PI over a concentration-tested range of $25 \mu \mathrm{g} / \mathrm{ml}$ to $1000 \mu \mathrm{g} / \mathrm{ml}$. An expressive proliferation delays was found after the treatment with herbicide at a dose of $250 \mu \mathrm{g} / \mathrm{ml}(\mathrm{P}<0.001)$, while the higher doses of 500 and $1000 \mu \mathrm{g} / \mathrm{ml}$ had caused nearly complete mitotic inhibition in each donor $(\mathrm{P}<0.05$ and $\mathrm{P}<0.001$, respectively). A correlation between the PI and $\mathrm{MI}$ inhibition refers rather to cytostatic than cytotoxic effects of the herbicide. The results support the possibility of immunosuppression by herbicide exposure.

Herbicide Modown, bovine peripheral lymphocytes, cell proliferation, cytostatic effect

Nitrodiphenylether herbicides are persistent and lipophilic environmental contaminants may contribute to the impairment of animal health and production. The presence of pesticide residues has been demonstrated in raw bovine milk and in different domestic animal tissues (Lioi et al. 1998).

All nitrodiphenylether herbicides exert their phytotoxic activity in chlorophyll of plants by the reduction itself to radical species, which initiate destructive reactions in membrane lipids, leading to the cell leakage (Corbett et al. 1984). Members, as acifluorfen and oxyfluorfen, e.g. are extremely potent inhibitors of protoporphyrinogen oxidase, a membrane-bound enzyme involved in the heme and chlorophyll biosynthesis pathways (Camadro et al. 1995). The later was studied for the induction of haematological diseases in human erythroid progenitor cells but a cytotoxic effect had been seen only at very high concentrations ( Rio et al. 1997).

Bifenox is a selective herbicide used in control of annual broad-leaved weeds and some grasses, e. g. in cereals, maize, soya beans, rice and other crops.

Jinno et al. (1999) described the cytotoxic and porphyrogenic effects of bifenox in rat hepatocytes. They found the maximum porphyrin accumulation at $0.25 \mathrm{mM}$ of the herbicide and an inhibion of protoporphyrogen oxidase, resulting in the accumulation of protoporphyrin IX.

Francis et al. (1999) evaluated maternal and developmental toxicity of ten diphenylether herbicides (including bifenox) in mice. They found a correlation among the position of chlorine substituents and the potential for inducing prenatal and postnatal syndroms. But no prenatal and postnatal embryotoxicity was shown. 
We investigated the in vitro dose-dependent effects of commercial herbicide bifenox (principal tradename Modown) on the mitogenic activity of bovine peripheral lymphocytes stimulated with phytohaemagglutinin (PHA). Previously we reported the results on chromosome aberrations and sister chromatid exchanges in bovine blood lymphocytes exposed to the herbicide in different sampling times - for the last $2 \mathrm{~h}, 24 \mathrm{~h}$ and $48 \mathrm{~h}$ of cultivation, respectively (Šiviková and Dianovský 1999). The statistically significant genotoxic effect was obtained in the sister chromatid assay after exposure to the herbicide for $24 \mathrm{~h}$ only. In the chromosome aberration assay no positive clastogenic effect was observed. From this point of view, references are quite scant. Considering the human and animal exposure to the herbicide, the results on lymphocyte proliferation kinetics can valuably complete data on the immmunotoxic potential of this agent possibly resulting in health consequences.

\section{Materials and Methods}

The commercial herbicide Modown (consists of bifenox, $\mathrm{C}_{14} \mathrm{H}_{9} \mathrm{Cl}_{2} \mathrm{NO}_{5}, 42 \%$, and $58 \%$ inert components composition not specified, Rhône - Poulenc, Toulouse, France) was dissolved into dimethyl sulfoxide (DMSO, Sigma, St. Louis, MO, USA) and applied into culture flasks. Concentrations of 25, 50, 250, 500 and $1000 \mu \mathrm{g} / \mathrm{ml}$ (except for the highest dose for cell proliferation kinetics assays) were used for treatments. The herbicide top doses were chosen on basis of the agent solubility and reduction in mitotic index (MI) $>50 \%$. The final DMSO concentration in the treated and control cultures was $0.1 \%$.

Experiments were carried out on two healthy cow donors (Slovak spotted cattle, 2- and 3-years-old).

Lymphocyte viability

Lymphocyte viability was studied by trypan blue exclusion test (Brusick 1984; Marzano et al. 1999). Cells were treated with the herbicide for the last $24 \mathrm{~h}$ and $48 \mathrm{~h}$, then incubated with $0.25 \%$ trypan blue (Sigma, St. Louis, MO, USA) and $10 \%$ foetal serum, for $4 \mathrm{~min}$. Viable cells were analysed at all the concentrations tested determining their ability to exclude dye.

Cell cultivation

Whole blood cultures $\left(0.5 \mathrm{ml}, 2.8 \times 10^{6}\right.$ cells $\left./ \mathrm{ml}\right)$ were cultivated for $72 \mathrm{~h}$ at $38^{\circ} \mathrm{C}$ in $5 \mathrm{ml}$ of RPMI 1640 medium supplemented with L-glutamine, $15 \mu$ M HEPES (Sigma, St. Louis, MO, USA), $15 \%$ foetal calf serum, antibiotics (penicillin $250 \mathrm{U} / \mathrm{ml}$ and streptomycin $250 \mu \mathrm{g} / \mathrm{ml}$ ), and phytohaemagglutinin (PHA, $180 \mu \mathrm{g} / \mathrm{ml}$, Welcome, Darford, England).

Lymphocyte cultures were exposed to the herbicide Modown for the last $24 \mathrm{~h}$ of cultivation and slides were obtained by the standard cytogenetic method; $2 \mathrm{~h}$ before harvest, colchicine (Merck, Darmstadt, Germany) was added at the concentration of $5 \mu \mathrm{g} / \mathrm{ml}$.

For the cell cycle kinetics bromodeoxyuridine $(8 \mu \mathrm{g} / \mathrm{ml}$, BrdUrd, Sigma, St. Louis, MO, USA) was added to all cultures $24 \mathrm{~h}$ after initiation of division. Slides were stained with the FPG (fluorescence plus Giemsa) technique to differentiate cell cycles (Perry and Wolff 1974).

One hundred metaphases per donor and concentration were analysed for determination of $\mathrm{M}_{1}$ (darkly stained chromatids), $\mathrm{M}_{2}$ (harlequin chromatids) and $\mathrm{M}_{3+}$ (part of metaphase with dark and light stained chromatids).

Proliferation index (PI) was calculated according to the formula: $\mathrm{PI}=\frac{\mathrm{M}_{1}+2 \mathrm{M}_{2}+3 \mathrm{M}_{3}}{100}$ (Lamberti et al. 1983).

Mitotic index was determined scoring the number metaphases in total number of 2000 cells. The inhibition of the mitotic index was calculated as $100-$ [MI treated x 100/ MI control] (Rojas et al. 1993).

Statistical analysis of results was performed from analysed cells using the Student's $t$-test for estimation of the cell cycle delay and $\chi^{2}$ test for reduction of MI.

\section{Results}

The dose - dependent effects of the herbicide Modown on the mitotic activity in bovine lymphocyte are shown in Fig. 1 and 2.

A statistically significant inhibition of the MI was detected after treatment with the highest herbicide concentrations of $500 \mu \mathrm{g} / \mathrm{ml}$ and $1000 \mu \mathrm{g} / \mathrm{ml}$ in both donors $(\mathrm{P}<0.05$ and $\mathrm{P}<0.001$, respectively). A more expressive decrease of mitotic activity was obtained with donor 2; so that a weak inhibition of the MI $(\mathrm{P}<0.05)$ was also seen after a dose of $250 \mu \mathrm{g} / \mathrm{ml}$ (Fig. 1).

The changes in the cell cycle proportions $\left(\mathrm{M}_{1}, \mathrm{M}_{2}\right.$ and $\left.\mathrm{M}_{3+}\right)$ were reflected in the proliferation delay (Fig. 2). The herbicide induced a cell cycle delay over a concentration 
range of $25 \mu \mathrm{g} / \mathrm{ml}$ to $500 \mu \mathrm{g} / \mathrm{ml}$ with a statistical significance at all the doses, except for the initial dose $(\mathrm{P}<0.05$ and $\mathrm{P}<0.001$, respectively). Even though an apparent decrease of total cell number was seen in comparison to the controls, no cytotoxicity had been confirmed with trypan blue dye test for 24 and $48 \mathrm{~h}$ of cultivation, respectively (data not shown). At the concentrations of 50 $\mu \mathrm{g} / \mathrm{ml}$ and $250 \mu \mathrm{g} / \mathrm{ml}$, the number of lymphocytes declined to about 50-70 \%, whereas the highest concentrations $(500$ and $1000 \mu \mathrm{g} / \mathrm{ml}$ ) resulted in nearly complete mitogenic inhibition. For $48 \mathrm{~h}$, similar results of viability were shown.

A correlation among the percentage of the MI and the PI inhibition demonstrated a negative slope line, Cache heride were obtained at the doses started of 250 or 500 characteristic of a cytostatic effect of the $\mu \mathrm{g} / \mathrm{ml}$ per donor, respectively.

herbicide (Fig. 3).

Fig. 1. Effect of the herbicide Modown on the mitotic index percentage of the MI in untreated and treated cultures. at the doses started of 250 or 500

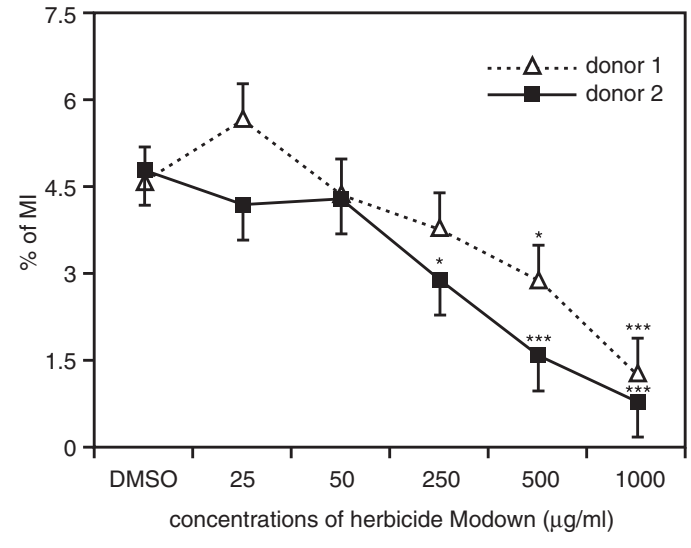
(MI) of cultured bovine lymphocytes. Data are presented as Calculations of the MI see in the methods. Positive effects of

\section{Discussion}

For the in vitro assays, the concentration scale of chemical agents up to a cytotoxic dose is required. Cytotoxicity is estimated from several endpoints, e.g. as cell death or cell confluence, that could be caused by the membrane disruption, osmotic shock or $\mathrm{pH}$ imbalance (Brusick 1984). For the blood lymphocyte cultures, a determination of the MI inhibition has a practical meaning (Preston et al. 1987; Armstrong et al. 1992; Kirkland 1998). The MI is interpreted in terms of the cell death or arrest of cells at any moment during the interphase. The later case would lead to an increase of the first metaphases along with a delay in the cell cycle that would affect the PI values.

Our results demonstrate inhibitions of the MI and PI at all the herbicide concentrations tested. Three highest concentrations of the herbicide $(250,500$ and $1000 \mu \mathrm{g} / \mathrm{ml}$ ) induced a statistically significant reduction in mitotic activity associated with the PI decrease $(\mathrm{P}<0.05$, $\mathrm{P}<0.001$, respectively).

Guadaño et al. (1998) reported that a parallel dose dependent decrease of the MI and PI indicates a cytotoxic effect of the herbicide. To differentiate cytotoxic and/or cytostatic effects of the chemical agent Rojas et al. (1993) suggested using a correlation between the MI and PI inhibition, which could also be used

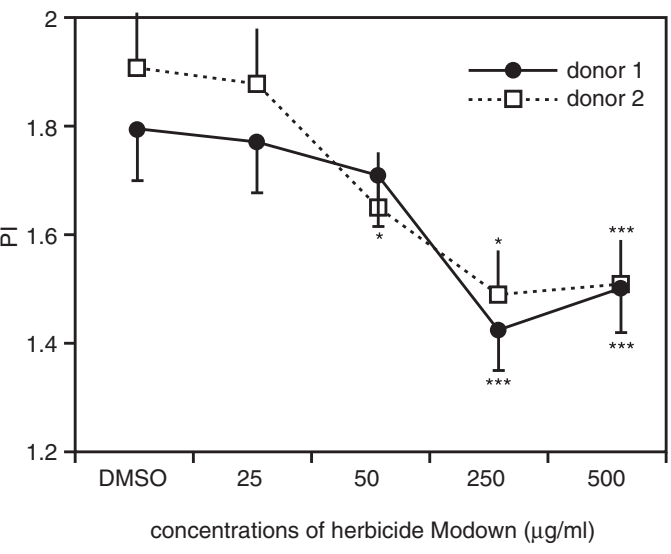

Fig. 2. Effect of the herbicide Modown on the proliferation index (PI) of cultured bovine lymphocytes (calculation of the PI see in methods). Positive effects of the herbicide were obtained at the doses started of 250 or $500 \mu \mathrm{g} / \mathrm{ml}$ per donor, respectively. 


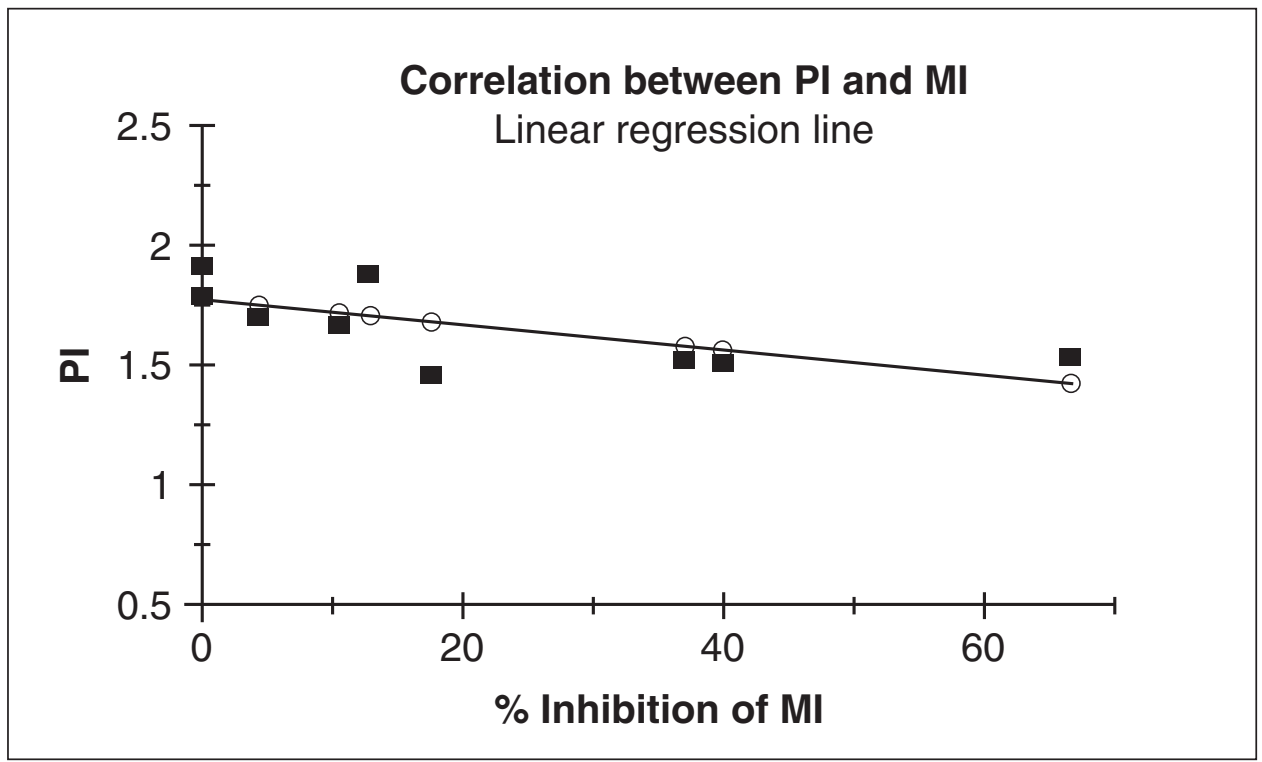

Fig. 3. Graphically analysed correlation between the inhibition of the PI and the MI (linear regression line). A negative slope of line is evident for agents with cytostatic activity. \% of inhibition of MI see in methods.

to predict the action of unknown compounds. In accordance with the proposed method a negative slope of the regression line was obtained in our experiments indicating a cytostatic effect of the herbicide Modown.

Similarly, Jinno et al. (1999) found no dose-dependent induced cytotoxicity in rat hepatocytes treated with bifenox at concentrations up to $1 \mathrm{mM}$.

Other members of diphenylether herbicides, e.g. oxyfluorfen, showed a cytotoxic effect in human erythroid progenitor cells only at very high concentrations $\left(10^{-4} \mathrm{M}\right)$, but no adverse effect on cellular proliferation was seen ( Rio et al. 1997).

Beside other toxic effects, the herbicides can also act on the immune system by stimulation or suppression of immune functions.

Blakley (1997) reported immunosupressive activity of 2,4 - dichlorophenoxyaceticacid herbicide in mice. Rat lymphocyte exposure to the same herbicide did not alter blastogenesis (Blakley et al. 1998). No effects on mitogen-induced proliferation or immunoglobulin synthesis were observed in human peripheral lymphocytes after exposure to polybrominated biphenylethers up to the concentrations of $10^{-5} \mathrm{M}$ (Fernlof et al. 1997). These authors presume that a certain function of human peripheral lymphocytes (proliferation and immunoglobulin synthesis) was intensive to the direct action of these agents.

Stelzer and Gordon (1984) documented the inhibition effects of pyrethroids (permethrin and cypermethrin) on human lymphocytes; similar results in the inhibition of mitogenic responses to concanavalin A and lipopolysaccharide were obtained, respectively. With respect to the similarity between the mitogenic inhibitory effect of permethrin and cypermethrin the authors take non-specific actions of these compounds.

Our results showed altered PHA mitogen responsiveness in the bovine peripheral lymphocytes. Involvement of membrane perturbing action of the herbicide in cellular function is not unexpected due to its high lipophilicity. More extensive experiments on immune suppression by the herbicide in vivo might support these results. 


\section{Mitotický index a bunková proliferačná kinetika ako prídavné varianty pri odhade genotoxického účinku herbicídu Modown}

Testovali sme schopnost herbicídu Modown (s aktívnou zložkou bifenoxom) ovplyvnit bunkovú proliferáciu PHA-stimulovaných periférnych lymfocytov hovädzieho dobytka in vitro. Ako alternatívu pre skríning cytostatickej aktivity látky sme zvolili mitotický (MI) and proliferačný (PI) index. Herbicíd Modown zapríčinil inhibíciu MI and PI vo všetkých testovaných koncentráciách od $25 \mu \mathrm{g} / \mathrm{ml}$ do $1000 \mu \mathrm{g} / \mathrm{ml}$. Výrazné proliferačné oneskorenie sme zistili po pôsobení herbicídu v dávke $250 \mu \mathrm{g} / \mathrm{ml}(\mathrm{P}<0.001)$, kým vyššie dávky 500 and $1000 \mu \mathrm{g} / \mathrm{ml}$ zapríčinili takmer úplnú mitotickú inhibíciu u oboch donorov $(\mathrm{P}<0.05$, resp. $\mathrm{P}<0.001)$. Korelácia medzi PI and MI poukazuje skôr na cytostatický než cytotoxický účinok herbicídu. Naše výsledky tiež podporujú možnost̉ imunosupresívneho účinku pri expozícii herbicídu.

\section{Acknowledgments}

The Ministry of Education and Science of the Slovak Republic (Grant No. 1/ 5150/98) supported this work.

\section{References}

ARMSTRONG, M. J., BEAN, CH. L., GALLOWAY, S. M. 1992: A quantitative assessment of the cytotoxicity associated with chromosomal aberration detection in Chinese hamster ovary cells. Mutat. Res. 265: 45-60.

BLAKLEY, B.R. 1997: Effect of roundup and tordon 202C herbicides on antibody production in mice. Vet. Hum. Toxicol. 39: 204-206.

BLAKLEY, B.R., YOLE, M.J., BROUSSEAU, P., BOERMANS, H., FOURNIER, M. 1998: Effect of 2,4 dichlorophenoxyacetic acid, trifluralin and triallate herbicides on immune function. Vet. Hum. Toxicol. 40: 5-10.

BRUSICK, D.J. 1984: Cytogenetic assays. Aberrations and SCE techniques. In Carcinogenesis and Mutagenesis Testing, (J.F. Douglas Ed.)Human Press Inc., Clifton, New Yersey, pp. 265-276.

CAMADRO, J.M., MATRINGE, M., THOME, F., BROUILLET, N., MORNET, R., LABBE, P. 1995 : Photoaffinity labeling of protoporphyrinogen oxidase, the molecular target of diphenylether-type herbicides. Eur. J. Biochem. 229: 669-674.

CORBETT, J. R., WRIGHT, K. BAILLIE, A. C. 1984: Herbicide interfering with photosynthesis. In The Biochemical Mode of Action of Pesticides, Jovanovich, H.B. (Publ.) Academic Press, London, pp. 50-93.

FERNLOF, G., GADHASSON, I., PODRA, K., DARNERUD, P. O. THUVANDER, A. 1997: Lack of effects of some individual polybrominated diphenyl ether (PBDE) and polychlorinated biphenyl (PCB) congeners on human lymphocyte functions in vitro. Toxicol. Lett. 90: 189-197.

FRANCIS, B. M., METCALF, R.L., LEWIS, P.A., CHERNOFF, N. 1999: Maternal and developmental toxicity of halogenated 4'- nitrodiphenyl ethers in mice. Teratology 59: 69-80

GUADAÑ̃, A., GONZÁLEZ-COLOMA, A., DE LA PEÑA, E. 1998: Genotoxicity of the insecticide rotenone in cultured human lymphocytes. Mutat. Res. 414: 1-7.

JINNO, H., HATAKEYAMA, N., HANIOKA, N., YODA, R., NISHIMURA, T., ANDO, M. 1999: Cytotoxic and porphyrinogenic effects of diphenyl ethers in cultured rat hepatocytes: chlornitrofen (CNP), CNP- amino, chlormethoxyfen and bifenox. Food. Chem. Toxicol. 37: 69-74

KIRKLAND, D. 1998: Chromosome aberration testing in genetic toxicology - past, present and future. Mutat. Res. 404: 173-185

LAMBERTI, L., PONZETTO, B. P., ARDITO, G. 1983: Cell kinetics and sister chromatid exchange frequency in human lymphocytes. Mutat. Res. 319: 193-199

LIOI, M. B., SCARFI, M. R., SANTORO, A., BARBIERI, R., ZENI, O., DI BERARDINO, D., URSINI, M. V. 1998: Genotoxicity and oxidative stress induced by pesticide exposure in bovine lymphocyte cultures in vitro. Mutat. Res. 403: 13-20

MARZANO, C., SEVERIN, E., FALCOMER, S., CHILIN, A. BORDIN, F. 1999: Cell killing and DNA damage induced in cultured mammalian cells by some tetrahydrobenzopsoralenquinones. Mutat. Res. 438: 133-143

PERRY, P., WOLFF, S. 1974: New Giemsa methods for differential staining of sister chromatids. Nature 251: 156-158

PRESTON, R. J., SAN SEBASTIAN, J. R., MC FEE, A. F. 1987: The in vitro human lymphocyte assay for assessing the clastogenicity of chemical agents. Mutat. Res. 189: 175-183

RIO, B., PARENT-MASSIN, D., LAUTRAITE, S., HOELLINGER, H. 1997: Effects of a diphenyl-ether herbicide, oxyfluorfen, on human BFU-E/CFU-E development and haemoglobin synthesis. Hum. Exp. Toxicol. 16: $115-122$

ROJAS, E., HERRERA, L.A., SORDO, M., GONSEBATT, M.E., MONTERO, R., RODRIGUEZ, R., OSTROSKY-WEGMAN, P. 1993: Mitotic index and cell proliferation kinetics for identification of antineoplastic activity. Anti-Cancer Drugs 4: 637-640 
STELZER, K. J., GORDON, M. A. 1984: Effects of pyrethroids on lymphocyte mitogenic responsivess. Res. Commun.Chem. Pathol. Pharm. 46: 137-148

ŠIVIKOVÁ, K., DIANOVSKÝ, J. 1999: Genotoxic activity of the commercial herbicide containing bifenox in bovine peripheral lymphocytes. Mutat Res. 439: 129-135 